\title{
ARTICLES
}

\section{Freedom of Religion and the Politics of the Liberal Public-Private Divide}

\author{
Daniel Augenstein
}

\section{A world of walls}

Michael Walzer famously suggested that we should think of liberalism 'as a certain way of drawing the map of the social and political world. ${ }^{1}$ Had society once been organized as an 'organic and integrated whole' in which aspects of religious and political life interpenetrated each other and constituted a 'single reality,' liberal theorists 'preached and practiced an art of separation':

'They drew lines, marked off different realms, and created the socio-political map with which we are still familiar. The most famous line is the "wall" between church and state, but there are many others. Liberalism is a world of walls, and each one creates a new liberty. ${ }^{3}$

For many liberals, the institutional 'wall' between state and church is built upon a separation of the public-as-secular from the religious-as-private. ${ }^{4}$ Historically, the evolution of the secular public sphere and the concomitant privatisation of religious diversity is said to have contributed to putting an end to the Christian bloodshed in Europe. ${ }^{5}$ This may in part explain the contemporary fear of some that religion might 'smuggle' itself back into the public sphere and endanger the 'citadel of the secular state.' ${ }^{\prime}$ But it also points to the paramount importance of liberal neutrality in attempts to justify its enduring exclusion. A secular understanding of the public, or so the argument goes, is justified by virtue of liberal neutrality because it secures a neutral public sphere in which citizens, stripped of their religious differences, can encounter each other as commons. In section two I

1 Michael Walzer, 'Liberalism and the Art of Separation,' Political Theory 12(3) (1984): 315.

2 Walzer, 'Liberalism,' 315.

3 Walzer, 'Liberalism,' 315.

4 As Walzer himself notes, the distinction between the public-as-secular and the religious-asprivate is but one manifestation of the liberal art of separation alongside, for example, the distinction between public politics and private economic activity, see Walzer, 'Liberalism,' 316. I shall focus on the distinction between the secular and the religious in order to shed some broader light on the way the public-private divide structures liberal politics.

5 Judith Shklar's 'liberalism of fear,' for example, was born out of the cruelties of the post-Reformation religious wars in Europe; see Judith Shklar, 'Liberalism of Fear,' in Varieties of Liberalism Today, ed. N. Rosenbaum (Cambridge, MA: Harvard University Press, 1989), 21, 13.

6 Andras Sajó, 'Preliminaries to a concept of constitutional secularism,' International Journal of Constitutional Law 6 (2008): 605-29. 
argue that this justification of the secular public sphere on grounds of liberal neutrality, while superficially attractive, is not conclusive because the distinction between the public sphere and the private sphere that is constitutive of liberal neutrality cannot be constituted by way of a neutral distinction between the (secular) public and the (religious) private.

My argument suggests that the justification of the liberal public-private divide rests on two distinct claims that are often lumped together: first, that the distinction between a 'public sphere' and a 'private sphere' is a meaningful way to cognize and structure modern pluralistic societies; and secondly, that there is a meaningful way to distinguish what is or ought to be 'public' from what is or ought to be 'private.' Both claims are of course interrelated: to posit something in the private sphere excludes it from the public sphere and such exclusion will appear arbitrary if it cannot be defended on the basis of a convincing delimitation of 'public' and 'private.' In this vein, critics of the liberal public-private divide have contested the distinction between the public sphere and the private sphere because it rests on a partisan understanding of public and private. ${ }^{7}$ Europe's (legal) treatment of its Muslim populations is a case in point. Not only does it cast doubts on the veracity of liberal attempts to carve out a protected private sphere of religious activity (instead of simply 'walling off' religious minorities). ${ }^{8}$ It also illustrates how the proper role of religion in the secular public sphere is defined with reference to national-majoritarian traditions imbued with Christian values, ${ }^{9}$ something perhaps most visible in the diverging treatment by the European Court of Human Rights (ECtHR) of the Muslim headscarf and the Christian crucifix. While the headscarf is portrayed as a 'powerful external symbol' that is 'difficult to reconcile with the message of tolerance, respect for others and, above all,

7 Ever since Habermas has drawn attention to the central importance of the public sphere for modern liberal democracy, critics have complained that rather than enabling rational public debate among citizens as equals, it creates an exclusionary space that perpetuates inherited power relations, see Jürgen Habermas, The Structural Transformation of the Public Sphere: An Inquiry into a Category of Bourgeois Society (Cambridge, MA: MIT Press, 1989) and the contributions collected in Habermas and the Public Sphere, ed. Craig Calhoun (Cambridge, MA: MIT Press, 1992). In his later work, Habermas has attempted to tackle the problem of the non-neutrality of liberal public sphere by submitting the very distinction between 'public' and 'private' to democratic deliberation under the moral point of view, which enjoins a mutual 'translation' requirement on secular and religious citizens, see Jürgen Habermas, 'Religion in the Public Sphere,' European Journal of Philosophy 14 (2006): 1-25; Jürgen Habermas, 'Religion in the Public Sphere: Cognitive Presuppositions for the "Public Use of Reason” by Religious and Secular Citizens,' in his Between Naturalism and Religion (Cambridge: Polity Press: 2008), 114-48.

8 See Amnesty International, Choice and Prejudice: Discrimination against Muslims in Europe (London: 2012).

9 As Mancini and Rosenfeld conclude their comparative survey, religious symbols-related conflicts in Europe "are often characterised in terms of a sharp antagonism between Islam and the Christian "West."' Whereas 'majority symbols are legitimized as representing cultural values that are universally shared by the citizenry,' the display of the Islamic headscarf is banned 'either as incompatible with certain core principles of a democratic system (frequently gender equality) or with democracy tout court,' see Susanna Mancini and Michael Rosenfeld, 'Unveiling the Limits of Tolerance,' in Law, State and Religion in the New Europe, ed. Lorenzo Zucca and Camil Ungureanu (Cambridge: CUP, 2012), 160, 182. 
equality and non-discrimination, ${ }^{, 10}$ the mandatory display of crucifixes in state schools does not suggest that the authorities were intolerant of pupils who believed in other religions.' 11

For all its national-majoritarian bias, I caution in section three against dismantling the liberal public-private divide because such strategy risks reinstating the liberal distinction between the 'secular public' and the 'religious private' as a totalistic distinction between 'national members' and 'Muslim non-members' of the polity as a whole. To elaborate this concern, I draw a trajectory from early-modern religious to contemporary nationalistic challenges to state-based liberalism (associated with, respectively, John Locke's treatment of the atheist and John Finnis' treatment of the Muslim) that collapse political community into predestined notions of religious faith and national fate. Against this background, I advance a less ambitious defence of the liberal public-private divide that vindicates the distinction between the public sphere and the private sphere not on grounds of a neutral distinction between the 'public' and the 'private' but instead as a discursive framework for conducting liberal politics. I submit that the proper response to concerns that the 'liberal public' is coterminous with the proverbial white heterosexual Christian male is not to abandon the distinction between the public sphere and the private sphere but to contest majoritarian conceptions of the public that underpin it. On this view that I shall flesh out in the final section, the distinction between the public sphere and the private sphere frames the negotiation of the 'public' and the 'private' between national majorities and religious minorities as members of the same political community.

\section{Laïcité}

The French tradition of laïcité is often considered the most principled expression of the liberal art of separation of the secular-as-public from the religious-asprivate. ${ }^{12}$ The French nation state assimilates the citoyen to its republican identity, while leaving her free to pursue her religious beliefs as a private individual. This separation of citizens' public and private 'selves' is legally entrenched through laïque state neutrality that purports to react with institutional blindness to the fact of religious and cultural diversity. As Poulter says:

'The principle of secularity (laïcité) is applied with particular fervour in France because the notion of modern citizenship as a status quite separate from distinctive ethnic identities and religious differences has become firmly

10 ECtHR, Dahlab v. Switzerland (Admissibility Decision of 15 February 2001).

11 ECtHR, Lautsi and Others v. Italy (Grand Chamber Judgment of 18 March 2011), paras 72-74.

12 Parts of this section draw on Daniel Augenstein, 'Normative Fault-Lines of Trans-National Human Rights Jurisprudence: National Pride and Religious Prejudice in the European Legal Space,' Global Constitutionalism 2 (2013): 469-97. There, I compare the French tradition of laïque republicanism with the German and the British approach to religious diversity and engage in a more systematic analysis of European case-law on religious symbols in the public sphere than I can provide for in the framework of my present philosophical argument. 
entrenched in the public mind ever since the days of the Revolution, as corollary of the classical republican principles of equality and fraternity. ${ }^{13}$

The principle of laïcité that commits French public schools to a strictly secular education was challenged in 1989 when three school girls insisted on wearing headscarves in class. The headmaster suspended the girls, claiming to apply a well-established rule of French republicanism prohibiting religious symbols in state schools. In the same year, the Conseil d'État gave a legal opinion holding that while the wearing of religious symbols in public schools was not in itself incompatible with the principle of laïcité, it could be restricted through ministerial decree in case it (among others) interfered with the peaceful running of schools. ${ }^{14}$ On this basis, the court reversed a number of school decisions suspending or excluding students who had refused to remove their headscarves. ${ }^{15}$ One decade later, on occasion of the publication of the Stasi Report, Jacques Chirac called in a controversial speech for a 'national mobilization in defence of the republic's secular values. ${ }^{\text {'16 }}$ The Stasi Report, after asserting that the principle of laïcité required a complete neutrality of the state in religious matters, had concluded that the headscarf controversy was no longer a matter of 'freedom of conscience' but of 'public order.' ${ }^{17}$ It recommended that educational institutions should provide better instruction on the values of republicanism and laïcité, and that 'ostentatious' symbols manifesting a religious affiliation should be banned. In 2004, the French parliament eventually passed a law prohibiting the wearing of any signs manifesting a religious affiliation in public schools. ${ }^{18}$

In September 2010, a further law was passed that makes it illegal to wear fullfaced veils anywhere in the public sphere. ${ }^{19}$ The report of the French National Assembly in preparation of the 2010 law employs language similar to that of the earlier Stasi Report, associating the veil with 'barbarity,' 'violence,' and the 'subju-

13 Sebastian Poulter, 'Muslim Headscarves in School: Contrasting Legal Approaches in England and France,' Oxford Journal of Legal Studies 17 (1997): 43, 50.

14 Conseil d'État, Avis nr. 346893 (27 November 1989), English summary in [1990] Public Law, 434-35.

15 In Kherouaa, Kachour, Balo, Kizic (Nr. 130.394, 2 November 1992), for example, the Conseil d'État struck down a school regulation on the ground that it was too general and indiscriminate, thus violating the pupils' freedom of religion; in Mlle Saglamer (Nr. 169.522, 27 November 1996) the court stressed that penalties for wearing a headscarf could only be applied if it was established that the behaviour of the pupil amounted to an act of pressure or proselytism or interfered with the public order in school. In Aoukili (Nr. 159.981, 10 March 1995), by contrast, it upheld the exclusion of students in the more specific context of physical education classes.

16 Cited in Dominik McGoldrick, Human Rights and Religion: The Islamic Headscarf Debate in Europe (Oxford: Hart, 2006), 82.

17 Commission de Réflexion sur l'application du principe de la laïcité dans la République, 'Rapport au Président de la République' (11 December 2003), paras 13, 58.

18 Loi no 2004-225 du 15 mars 2004 encadrant, en application du principe de laïcité, le port de signes manifestant une appartenance religieuse dans les écoles, collèges et lycées public.

19 Loi no 2010-1192, Journal Officiel de la République Française (12 October 2010). 
gation' of women incompatible with Europe's 'Spirit of Enlightenment.'20 In October 2010, the Conseil Constitutionnel upheld the constitutionality of the ban without, however, explicitly pronouncing on laïcité. Instead, the Court accepted Parliament's assessment that full-faced veils place women in a situation of exclusion and inferiority incompatible with constitutional principles of liberty and equality. ${ }^{21}$ In July 2014, the Grand Chamber of the European Court of Human Rights joined the view of the French constitutional court. ${ }^{22}$ The Strasbourg judges noted that the 2010 law confronts the applicant with a 'dilemma': 'either she complies with the ban and thus refrains from dressing in accordance with her approach to religion; or she refuses to comply and faces criminal sanctions. ${ }^{23}$ Nevertheless, having emphasized (as it always does) 'the State's role as the neutral and impartial organiser of the exercise of various religions, faiths and beliefs, ${ }^{24}$ the Court accepted the French government's argument that 'the voluntary and systematic concealment of the face is problematic because it is quite simply incompatible with the fundamental requirements of "living together" in French society.' 25

At first sight, the French ban of religious symbols from the public sphere seems to keep with the promise of liberal neutrality. After all, limits on the exercise of religion are justified by virtue of securing a neutral-as-secular public sphere and guaranteeing the equal protection of religious freedom in the private sphere. However, such an argument overlooks that the laïque public sphere is itself the result of a historical process coined by an interrelation of Christianity and secularization. Accordingly, as Hervieu-Léger notes,

'[i]t is impossible to appreciate the discussion of many questions in French public life which have nothing strictly to do with religion (from food quality to the ethical regulation of science, the management of hierarchical relationships in business, the future of rural society, societal expectations of the state, and demands for workers' rights) without being aware of the extent to which French culture is impregnated with Catholic values. ${ }^{26}$

Laïcité is a non-neutral principle in a twofold sense. Most obviously, while it claims to treat different religious equally it cannot be neutral between religious and secular worldviews as such. It may be argued that this is what comes with liv-

Assemblée nationale, 'Rapport d'information n. 2262, au nom de la mission d'information sur la pratique du port du voile intégral sur le territoire national' (26 January 2010); see further Mancini and Rosenfeld, 'Unveiling the Limits of Tolerance,' 174-77.

21 Conseil Constitutionnel, Décision no 2010-613 DC (7 October 2010). The law was upheld except for its ban of full-faced veils in public places of worship.

22 ECtHR, SAS v. France (Grand Chamber Judgment of 1 July 2014).

23 ECtHR, SAS v. France, para 110.

24 ECtHR, SAS v. France, para 127.

25 ECtHR, SAS v. France, para 141.

26 Danièle Hervieu-Léger, 'The Role of Religion in Establishing Social Cohesion,' in Religion in the New Europe, ed. Krzysztof Michalski (Budapest: Central European University Press, 2006), 45, 51. 
ing in a secularized liberal state. Yet my point is that there is no necessary inference from endorsing secularism to the justification of the ban of religious symbols from the public sphere on grounds of liberal neutrality. But laïcité even fails on the weaker claim of neutrality between different religions. Put crudely, French Christian secularists and secularized Christians will find it much easier to accept the public-private divide with its privatization of religious freedom simply because they contributed to its creation in the first place. Laïcité does not require them to change their dress, behaviour and customs regarding the role of religion in the public sphere. ${ }^{27}$ And it is, as Modood remarks, surely a contradiction to require both that the secular state should be neutral between religions and that the secular state should require certain religions to renounce their public ambitions. ${ }^{28}$ It may be objected that laïcité is at least neutral in the sense that it does not aim at discriminating between different religions, and/or that it does not draw on religious justifications. However, such models of formal or reason-based equality hide as much as they reveal. They cannot determine whether liberal neutrality requires religions to be treated equally in a positive sense (all religions in the public sphere), or equally in a negative sense (all religions out of the public sphere). But surely, this is precisely what is at stake in the contest between 'public' and 'private' religions - which leads right back to the primordial problem of defining what should count as 'public' and 'private' for the purpose of the liberal public-private divide.

Once the veil of liberal neutrality is lifted, two further justifications for decreeing public religions as private divide surface: laïcité as promotion of individual autonomy that lies at the heart of a perfectionist morality; and laïcité as a communitarian ideal that fosters a civic sense of loyalty to a particular historical community. ${ }^{29}$ For those who defend the equation of 'secular' and 'public' on grounds of individual autonomy, the ban of religious symbols from the public sphere is justified because it liberates Muslim women from heteronomous social structures that persist in the private sphere - a position enthusiastically endorsed by former French President Sarkozy when advocating the French burqa ban: 'The burqa is not a religious sign. It is a sign of the subjugation, of the submission, of women. (...) We cannot accept in our country women imprisoned behind bars, cut off from social life, deprived of identity.' 30 The blemish of this heroic posture is that it becomes self-defeating once placed in the context of the liberal public-private divide: the autonomy of Muslim women is promoted by excluding them from the autonomous public sphere and forcing them back into the heteronomous private sphere that deprives them of their 'identity.' This entails a categorical denial that Muslim women could embrace the headscarf as an autonomous choice, that is, as

27 Anna E. Galeotti, Toleration as Recognition (Cambridge: CUP, 2002), 127-28.

28 Tariq Modood, 'Anti-Essentialism, Multiculturalism and the "Recognition" of Religious Groups,' Journal of Political Philosophy 6 (1998): 378, 393.

29 Cecile Laborde, 'Toleration and laïcité,' in The Culture of Toleration in Diverse Societies, ed. Catriona McKinnon and Dario Castiglione (Manchester: Manchester University Press, 2003), 161-78.

30 Cited in Doreen Carvajal, 'Sarkozy Backs Drive to Eliminate the Burqa,' The New York Times, 23 June 2009. 
a self-conscious expression of their struggle to define their place as female Muslims in the secularized Christian nation state. As Balibar remarks, what gets lost in the relentless crusade of secular autonomy against sacred heteronomy is the tragic character of a situation in which Muslim women 'become the stake of a merciless struggle for prestige between two male powers which try to control them, one on behalf of patriarchal authority wrapped up in religion, the other on behalf of national authority wrapped up in secularism.' ${ }^{31}$

This leaves the third and final tenet of laïcité, a communitarian notion of civic loyalty that strives to resurrect a 'traditional Catholic-inspired sociability' in new national clothes. ${ }^{32}$ On this view, the ban of religious symbols from the secular public sphere is justified because it inculcates a robust national identity capable of transcending particular religious and cultural loyalties. Stripped of its neutralist pretensions the conversion of believers into citizens works through the imposition of national majoritarian traditions on religious minorities. During the parliamentary debates of the 1994 French law prohibiting the display of religious symbols in public schools, a member of the Assemblée Nationale used his 'bon sens paysan' to elaborate a contemporary interpretation of the traditional French way of transforming (Catholic) 'peasants into Frenchmen': 'Islam has settled rather recently in our country. Its faith is absolutely respectable. But its adherents, as everybody else, must adapt to our values and traditions, not the other way around.' ${ }^{3}$ Ultimately, the 'neutrality' and 'autonomy' justifications for excluding religious symbols from the public sphere collapse into this kind of national majoritarianism that betrays the liberal promise not just to assimilate but to transcend religious diversity. ${ }^{34}$ National majorities posit the distinction between the secular public sphere and the religious private sphere in order to populate the former and relegate religious minorities to the latter. It is their national and secular and Christian conception of 'public' that directs the neutrality principle towards the exclusion of (certain) religions from the public sphere, as it is their national and secular and Christian conception of 'private' that reduces the political subject behind the veil to a false dichotomy between secular autonomy and sacred heteronomy.

31 Etienne Balibar, 'Dissonances within Laïcité,' Constellations 11 (2004): 353, 359.

32 See Laborde,'Toleration and laïcité,' 170.

33 Journal Officiel de la République Française 17(2) (2004), A.N. (C.R.), at 1463 ; 'L'islam est d'implantation relativement récente chez nous. Sa croyance est parfaitement respectable. Mais, comme pour toutes les autres, c'est aux tenants de cette religion de s'adapter à nos valeurs et traditions et non l'inverse.'

34 From a socio-anthropological perspective, John Bowen shows how laïcité has been invoked strategically in the French public debate leading up to the 2004 law in order to address broader concerns surrounding headscarves in France (the growth in 'communalism' at the expense of social mixing; the increasing influence of international 'Islamism' on French society; and the denigration of women in the poor suburbs) and to justify claims for assimilation to what is portrayed as shared French republican values, see John R. Bowen, Why the French Don't Like Headscarves: Islam, the State, and Public Space (Princeton: Princeton University Press, 2008). 
On a more analytical plane, the purportedly 'neutral' distinction between the public-as-secular and the religious-as-private displays the public-private divide as both constitutive of and constituted by liberal neutrality. It is constitutive of liberal neutrality in that the division of society into a public sphere and a private sphere demarcates the realm in which liberal neutrality is properly thought to apply. Liberal neutrality thus presupposes the existence of a public sphere as separated from other social spheres defined as private. Yet the public-private divide is also constituted by liberal neutrality in that the latter is thought to provide the justification for a non-arbitrary distinction between the public and the private. This justification of the secular public sphere on grounds of liberal neutrality is not conclusive because liberal neutrality can only apply to the public sphere after a non-neutral distinction between public and private has been put into place. Put differently, the secular public sphere can only be neutral between different religions if and to the extent that all religions have already been demarcated as private.

\section{Our modern atheists}

The problem of the non-neutrality of liberal neutrality is everything but new. If, John Locke had argued in his Epistola de Tolerantia of 1689,

'such were the state of things, that the interest of the commonwealth required all slaughter of beasts should be forborne for some while, in order to the increasing of the stock of cattle, that had been destroyed by some extraordinary murrain; who sees not that the magistrate, in such a case, may forbid all his subjects to kill any calves for any use whatsoever? Only it is to be observed, that in this case the law is not made about religion, but about political matter; nor is the sacrifice, but the slaughter of calves thereby prohibited.'35

However, while the farmer who cannot kill his calf until the stock has been sufficiently increased will merely suffer a temporal economic disadvantage, the religious believer, when not engaging in the rituals required by her faith, will risk her salvation. And it is difficult to see why Locke's proposal should seem equally congenial to both of them. ${ }^{36}$ That the law is not made about religion is simply not sufficient to establish its neutrality in relation to religion.

But the problem cuts deeper. As is well known, Locke's defence of religious toleration was not particularly tolerant after all, despite his claim to have drawn a bright-line distinction between the 'business of civil government' and the 'busi-

35 The Epistola de Tolerantia was first published anonymously in Latin in 1689. Citations refer to the initial English translation by William Popple, as reprinted in John Locke's Letter On Toleration in Focus, ed. Susan Mendus and John Horton (London: Routledge, 1991), 12, 37.

36 See further Stanley Fish, 'Mission Impossible: Settling the Just Boundaries between Church and State,' Columbia Law Review 97 (1997): 2255-333. 
ness of religion.' Having established that the power of the Magistrate was confined to protecting the 'civil order of the Commonwealth,' Locke was quick to identify certain (religious) doctrines that nevertheless came under his jurisdiction because they posed a threat to that very order. Thus, having argued that 'Mahometans' should not be excluded from the civil rights of the Commonwealth because of their religion, Locke maintained that a Church

'can have no right to be tolerated by the magistrate, which is constituted upon such a bottom, that all those who enter into it, do thereby, ipso facto, deliver themselves up to the protection and service of another prince. (...) It is ridiculous for anyone to profess himself to be a Mahometan only in religion, but in everything else a faithful subject to a Christian magistrate, whilst at the same time he acknowledges himself bound to yield blind obedience to the Mufti of Constantinople; who himself is entirely obedient to the Ottoman emperor.' $^{\text {'37 }}$

Put more bluntly, the Magistrate must use his 'rods and axes' against his Catholic subjects because their obedience to the Pope undermines his political authority. ${ }^{38}$ The same goes for those 'who deny the being of God' because 'promises, covenants, and oaths, which are the bonds of human society, can have no hold upon an atheist. ${ }^{39}$ Importantly, Locke does not simply say that some Catholics and atheists may pose a threat to public order - he claims that this is always and necessarily the case because the threat lies in the very nature of being a Catholic or atheist. Moreover, Locke does not merely propose to confine their rights to express their religious (non-)beliefs to the private sphere. Rather, Catholics and atheists must be denied the civil rights of the Commonwealth altogether because they have placed themselves outside the civil order and the bonds of human society: 'the taking away of God, though but even in thought, dissolves everything. ${ }^{40}$

Why bother? After all, few people in the liberal West today would still subscribe to the Lockean proposition that Catholics undermine the political authority of the secular state, and even fewer people are likely to believe that atheists are immoral and cannot be trusted. Locke's argument is tailored to a Christian society in a Christian state, and is therefore unlikely to raise much excitement in a contemporary audience. ${ }^{41}$ Nevertheless, there may still be some dystopian lessons to be learnt from the way Locke disqualifies certain (religious) doctrines from membership in the liberal society - for liberal societies in which Locke's rhetorical 'Mahometans' have come to claim a real presence. Sometime back,

38 Jeremy Waldron thinks that Locke should be read literally here, thus charging Muslims rather than Catholics - which would serve my argument just as well, see Jeremy Waldron, God, Locke and Equality (Cambridge: CUP, 2002), 221.

39 See Locke, John Locke's Letter, 47.

40 Locke, John Locke's Letter, 47.

41 John Dunn, 'What is Living and What is Dead in the Political Theory of John Locke?,' in Interpreting Political Responsibility (Cambridge: CUP, 1990), 2-26. 
Brian Barry alerted us that we are likely headed for 'a new Dark Age' that betrays the Enlightenment hope that the cessation of persecution and censorship would lead to the triumph of liberal attitudes. ${ }^{42}$ On the one hand, 'there is little chance of selling neutrality to non-liberals, which means that non-liberals will continue to hold views about the proper role of state action that run counter to liberal policy prescriptions.' On the other hand, the 'prospects of survival' of liberal institutions depends on 'there being in the population a large proportion of people with a liberal outlook. ${ }^{43}$ More recently, John Finnis has found new evidence in support of the Dark Age thesis in the jurisprudence of the European Court of Human Rights. ${ }^{44}$ According to Finnis, the Chamber and the Grand Chamber judgment of the Strasbourg court in Şahin show that the British House of Lords in Begum did not say what it really wanted to say. ${ }^{45}$

What the majority of British judges did say in Begum was that the decision of Denbigh High School to prohibit Shabina Begum attending school dressed in a jilbab (a long loose-fit overgarment) did not interfere with her right to freedom of religion under Article 9 of the European Convention on Human Rights (ECHR) because she could choose to 'compromise and, if necessarily sacrifice' the expression of her beliefs, or to move to another school whose uniform policy would accommodate her religious dress requirements. ${ }^{46}$ Moreover, all judges concurred that assuming there had been an interference, it would have been justified because the school's uniform policy pursued the legitimate aim of protecting the rights and freedoms of others by promoting social cohesion and religions harmony among opposing groups. Finnis is right to complain about such 'conceptual slackness of human rights-law-in-action. ${ }^{47}$ That the uniform policy may compel Begum to 'sacrifice' the expression of her religious beliefs is not considered sufficient to bring her case within the ambit of Article 9(1) ECHR. This, in turn, relieves the school from the onus of proving that Begum's exclusion was 'necessary in a democratic society' because responding to a 'pressing social need' as required by Article 9(2) ECHR. ${ }^{48}$

This is what Finnis thinks the House of Lords really wanted to say:

'Confronted by the grave warnings thus issuing from courts of great panEuropean authority, citizens of countries whose Muslim population is

42 Brian Barry, 'How Not to Defend Liberal Institutions,' in Liberalism and the Good, ed. Robert Douglass et al. (London: Routledge, 1990), 44, 57.

43 Barry, 'How Not to Defend Liberal Institutions,' 56.

44 John Finnis, 'Endorsing Discrimination Between Faiths: A Case of Extreme Speech?,' in Extreme Speech and Democracy, ed. Ivan Hare and James Weinstein (Oxford: OUP, 2009), 430-44.

45 See, respectively, ECtHR, Leyla Şahin v. Turkey (Judgement of 29 June 2004); ECtHR, Leyla Şahin v. Turkey (Grand Chamber Judgement of 10 November 2005); and House of Lords, Regina (SB) $v$. Governors of Denbigh High School [2006] UKHL 15 (Begum).

46 See Begum, paras 50, 54.

47 See Finnis, 'Endorsing Discrimination Between Faiths,' 433.

48 For a more detailed analysis see Nicholas Gibson, 'Faith in the Courts: Religious Dress and Human Rights,' Cambridge Law Journal 66 (2007): 657-97. 
increasingly very rapidly by immigration and a relatively high birth rate may ask themselves whether it is prudent, or just to the children and grandchildren of everyone in their country, to permit any further migratory increase in that population, or even to accept the presence of immigrant, non-citizen Muslims without deliberating seriously about a possible reversal - humane and financially compensated for and incentivized - of the inflow. ${ }^{49}$

Now clearly, their Lordships could not have said what Finnis thinks they wanted to say after Lord Bingham had found it 'important to stress at the outset that this case concerns a particular pupil in a particular school in a particular place at a particular time. ${ }^{50}$ So let's turn to the 'grave warnings' issued by the European Court of Human Rights. According to Finnis, the outcome of Şahin was predictable after the ECtHR had upheld the ban of the Turkish Refah Party, among others because Refah Partisi had advocated and intended to introduce Islamic law in Turkey. ${ }^{51}$ Leyla Şahin, by contrast, only wanted to continue her university education wearing a headscarf. Istanbul University suspended her, a decision that the ECtHR eventually upheld in a split Grand Chamber Judgement. Before the Strasbourg court, the Turkish government did not submit, let alone substantiate, that Ms Şahin was connected to extremist political movements, or that she had ever tried to impose her religious views on others. ${ }^{52}$ Which is why the Chamber judges contented themselves with accepting the Turkish Government's view that the headscarf ban was justified as a general 'preventive' measure. ${ }^{53}$ The Grand Chamber, after cursorily observing that 'the impugned interference primarily pursued the legitimate aim of protecting the rights and freedoms of others and of protecting public order,' considered that it could not 'apply the criterion of proportionality in a way that would make the notion of an institution's "internal rules" devoid of purpose. 54 Whatever 'warnings' the Strasbourg judges may have wanted to convey, they would be based on very tangible evidence indeed. Judge Tulkens' lone dissent in Şahin rings true: 'only indisputable facts and reasons whose legitimacy is beyond doubt - not mere worries or fears - are capable of (...) justifying interference with a right guaranteed by the Convention.' 55

49 See Finnis, 'Endorsing Discrimination Between Faiths,' 440.

50 See Begum, para 2.

51 See Finnis, 'Endorsing Discrimination Between Faiths,' 436; ECtHR, Refah Partisi and Others $v$. Turkey (Judgement of 31 July 2001) and ECtHR, Refah Partisi and Others v. Turkey (Grand Chamber Judgement of 13 February 2003).

52 The applicant, by contrast, accepted the importance of upholding the principle of secularism and the neutrality of Turkish universities, but maintained that her wearing a headscarf had not caused any disruption, disturbance or threat to the public order. In her view, the headscarf did not threaten republican values or the rights of others, nor could it be regarded as inherently incompatible with the principle of secularism and the neutrality of education, see Şahin 2004, paras 83-88.

53 Şahin 2004, para 96.

54 See Şahin 2005, para 99.

55 Şahin 2005, Dissenting Opinion of Judge Tulkens, para 5. 
The problem with Finnis' interpretation is that it confuses the Court deferring to the views of the Turkish authorities with the Court endorsing these views. Indeed, the ECtHR's justification for employing a wide margin of appreciation is a far cry from Finnis' contention that the Court could indulge his own view, namely that the 'intimidatory pressures for conformity which are the main ground for the headscarf ban in Turkey and the jilbab ban in Denbigh High School are often (...) early precursors of jihad': ${ }^{6}$

'Where questions concerning the relationship between State and religions are at stake, on which opinion in a democratic society may reasonably differ widely, the role of the national decision-making body must be given special importance. This will notably be the case when it comes to regulating the wearing of religious symbols in educational institutions, in respect of which the approaches in Europe are diverse. Rules in this sphere will consequently vary from one country to another according to national traditions and the requirements imposed by the need to protect the rights and freedoms of others and to maintain public order. ${ }^{57}$

In an earlier contribution, John Finnis defended the indefinite detention of (Muslim) non-citizens awaiting deportation on grounds of a Kelsenian notion of the 'legal system's subsiding unity through time [that] cannot be explained without foundational reference to the group whose legal system it is. ${ }^{58}$ The background of the debate was a House of Lords judgment holding that the indefinite detention of foreigners suspected of terrorist activities was incompatible with the European Convention on Human Rights because it arbitrarily discriminated between UK nationals and UK non-nationals. ${ }^{59}$ For Finnis, by contrast, it is precisely the distinction between nationals and aliens that breathes life into the legal community because it endows the indispensable framework for articulating, expressing, ratifying, and demanding (...) integration in and assimilation to this nation-state rather than some other': ${ }^{60}$

'Here our constitutional law intervenes to remind us that while they are among us, non-members are to be treated as members so far as is compatible with maintaining the core of the distinction between members and nonmembers - between members by right and members by revocable permission. So our justifiable lesser willingness to accept risks from non-members warrants (...) their liability to be removed from the nation's territory and, with a view to and pending that removal, to be kept apart from the community by humane detention or control. ${ }^{61}$

56 See Finnis, 'Endorsing Discrimination Between Faiths,' 439.

57 See Şahin 2005, paras 108-9.

58 John Finnis, 'Nationality, alienage and constitutional principle,' Law Quarterly Review 123 (2007): 417, 443.

59 House of Lords, A and others v. Secretary of State for the Home Department [2004] UKHL 56.

60 See Finnis, 'Nationality, alienage and constitutional principle,' 444.

61 Finnis, 'Nationality, alienage and constitutional principle,' 444-45. 
However, as Finnis himself realizes, the conferral of citizenship as a legal status does not vouch for membership in the national community. The deeper challenge to constitutional order, he concludes, is 'posed by nationals who regard their nationality as a form of alienage because (...) they believe their true Nation lies altogether beyond - but is ordained to have dominion over - the bounds and territories, and the constitutional principles and rights, that frame and structure our nation's common good.' ${ }^{62}$ Locke could not have put it any better. It is ultimately a concern with national membership, not legal citizenship, which motivates Finnis' proposal to prevent any further Muslim migration and reverse the inflow of Muslim immigrants. That we are (sometimes ${ }^{63}$ ) legally prevented from deporting Muslim nationals is just a tedious detail in the real debate about whether Muslims can be genuine members of the national community at all.

John Dunn has suggested that Locke's fear of atheism could be considered 'a sort of spiritual equivalent to AIDS in the most hysterical and contemporary understandings. ${ }^{\prime} 4$ The atheist's denial of the existence of God reduces the law of nature to the conflictive interests of individuals who, left to their own fallible devices, have no reason to trust each other and hence no capacity to form a peaceful and stable society. Jeremy Waldron has defended Locke's exclusion of 'Mahometans' against liberal critique by arguing that Locke could concede the possibility that not all Muslims yielded blind political obedience to the Ottoman emperor. ${ }^{65}$ One question is whether Locke and his contemporaries believed that for a 'Mahometan' to profess himself a faithful subject of the Magistrate could be anything but 'ridiculous' pretence. ${ }^{66}$ Another question is whether today's liberal majorities upon whom the 'prospects of survival' of liberal institutions depend have once again come to believe the same. If so, and to invert John Dunn's conclusion, Locke is very alive and liberalism is 'well and truly dead.' 67

\section{The politics of the liberal public-private divide}

Europe and the nation-states of which it is constituted, Talal Asad argues in his excellent anthropological study of the formations of the secular, 'is ideologically constructed in such a way that Muslim immigrants cannot be satisfactorily represented in it.' They are 'included within and excluded from Europe at one and the same time (...), [which] has less to do with the "absolute Faith" of Muslims living in a secular environment and more with European notions of "culture" and "civilization" and "the secular state," "majority" and "minority."68 European identity

62 Finnis, 'Nationality, alienage and constitutional principle,' 445.

63 Under the amended UK Immigration, Asylum and Nationality Act 2006, British citizens who hold a double nationality can be deprived of their citizenship if the Secretary of State is satisfied that the deprivation is 'conductive to the public good.'

64 See Dunn, 'What is Living,' 19.

65 See Waldron, God, Locke and Equality, 221.

66 See Locke, John Locke's Letter, 46-47.

67 See Dunn, 'What is Living,' 9.

68 Talal Asad, Formations of the Secular (Stanford: Stanford University Press, 2003), 159. 
'concerns exclusions and the desire that those excluded recognize what is included in the name one has chosen for oneself.' ${ }^{69}$ Asad is sceptical about the potential of representative democracy to overcome the national-majoritarian bias of the liberal democratic state:

'The ideology of political representation in liberal democracies makes it difficult if not impossible to represent Muslims as Muslims. Why? Because in theory the citizens who constitute a democratic state belong to a class that is defined only by what is common to all its members and its members only. What is common is the abstract equality of individual citizens to one another, so that each counts as one. (...) Involved here is the assumption not only that the whole is authoritative over any of its parts, but that what there is more of has ipso facto greater weight than that which differs from it merely by being less. ${ }^{70}$

In section two, I argued that attempts to justify what is 'common to all members' of the liberal polity on grounds of a neutral distinction between the public-assecular and the religious-as-private are bound to fail because the secular public sphere can only be neutral between different religions if and to the extent that all religions have already been demarcated as private. At the same time, my analysis in section three suggested that it is precisely this purported abstract commonality between citizens in the public sphere that vouches for their political membership in the liberal state irrespective of their 'private' religious loyalties. This is not to suggest that the evolution of the public sphere coincided with the emergence of state-based liberalism. ${ }^{71}$ It is only to maintain that within the modern state, the liberal distinction between the public sphere and the private sphere is a manifestation of the relative autonomy of the political subject from predetermined orders of social relations. Different from pre-modern notions of hierarchy and transcendental order that a priori imputed social meaning to the collective, the liberal public sphere emplaces the citizen in a 'community of strangers' bonded by an impersonal solidarity generated through the process of political self-determination whose operative logic remains distinct from the society over which it rules. $^{72}$

Accordingly, dismantling the distinction between the public sphere and the private sphere does little to neutralize national-majoritarian conceptions of the 'public' but instead allows them to colonize society in its entirety, thus bereaving religious minorities of their last refuge. The likely result is a reinstatement of the liberal distinction between the 'secular public' and the 'religious private' as a total-

69 Assad, Formations of the Secular, 161.

70 Assad, Formations of the Secular, 173.

71 Hannah Arendt, for example, traces the distinction between the public sphere and the private sphere to a corresponding distinction between the polis and the household/family in the ancient Greek city-state, see Hannah Arendt, The Human Condition (Chicago: University of Chicago Press, 1958).

72 Ian Loader and Neil Walker, Civilising Security (Cambridge: CUP, 2007), 176-82. 
istic distinction between 'national members' and 'Muslim non-members' of the polity as a whole. This predicament, in turn, reveals the critical role of the liberal private sphere in securing religious minorities a vested interest in society by allocating them a protected space for the development and expression of values that have not (yet) been recognized by national-majoritarian traditions and cultures. ${ }^{73}$ Perhaps needless to say, propositions of the like are routinely discredited on the ground that they allegedly foster the formation of 'secluded communities' that become insulated from the critique of society. More often than not, such allegations build on a comfortable yet incongruous equation of 'society' with 'majority' that nourishes the furore of one (dominant) part of society that another (subordinate) part of society resists the assimilation to cultural norms and practices that, in effect or intention, denigrate and exclude them. Be that as it may, I do not wish to suggest that the liberal public-private divide could or should create a non-permeable and immutable wall of separation between state and society. On the contrary, the liberal distinction between the public sphere and the private sphere provides the discursive framework for negotiating the 'public' and the 'private' between national majorities and religious minorities as members of the same political community.

Asad's insight that European identity demands that those excluded recognize what is included in its own name points to a different, non-numerical and reflexive, understanding of political representation as collective self-identification. ${ }^{74}$ On this view, political community is constituted by virtue of a legal act that identifies and empowers individuals as its members. Yet 'this identification/ empowerment only succeeds if individuals retroactively identify themselves as the members of the polity. ${ }^{.75}$ It is the representation of the people as a political community (the 'we') that is constitutive of its individuation and legitimized through its reiteration on the part of the real people that come to be re-presented. The re-presented origin of a political community, in turn, explains the precarious and ever-provisional legitimacy of legal ordering which is 'from the very beginning [beset with] the problem of justifying the inclusion and exclusion required for political unity': ${ }^{76}$

'For the democratic Rechtsstaat is the form of political organisation that suspends, up to a point, the initial and subsequent closures in view of determining anew what interests are shared by a community and who is an interested party thereto. Moreover, this suspension and redefinition of closure are only possible because the legal order, as posited, does not exhaust the possibilities of political community. ${ }^{\text {77 }}$ Hans Lindahl, 'Constituent Power and Reflexive Identity: Towards an Ontology of Collective Selfhood,' in The Paradox of Constitutionalism, ed. Martin Loughlin and Neil Walker (Oxford: OUP, 2007), 9, 14.

75 Lindahl, 'Constituent Power and Reflexive Identity,' 19.

76 Lindahl, 'Constituent Power and Reflexive Identity,' 22.

77 Lindahl, 'Constituent Power and Reflexive Identity,' 23. 
The reflexive nature of political representation that confronts the legal order with the unrealized possibilities of political community ties into the importance of the public-private divide as a discursive framework for conducting liberal politics. If, pace Finnis, the distinction between nationals and aliens is a prerequisite for the subsiding unity of the legal system, the distinction between the public sphere and the private sphere is under contemporary conditions of religious and cultural pluralism a prerequisite for the subsiding unity of the political community to which the legal system refers. It provides the framework for articulating and ratifying not only what it means to belong to the nation state but also what it means to belong to the nation state. The exclusion qua public from the public sphere contains a simultaneous inclusion qua private in the private sphere that is premised upon the inclusion of the excluded in the political community as a whole. My point is not simply that the exclusion of religious minorities from the public sphere entails their inclusion in the private sphere and vice versa. It is, more fundamentally, that their coinstantaneous exclusion from the public sphere and inclusion in the private sphere entails the recognition of their enduring membership in a political community in which belonging is not conditional on religious faith or national fate. The politics of the liberal public-private divide thus tames the aggressive reanimation of religious and national ideologies that reduce the distinction between majoritarian publics and minoritarian privates to a primordial opposition of friend and foe, purchasing national solidarity at the price of stigmatizing 'an enemy within. ${ }^{\text {78 }}$

With historical hindsight, Locke was wrong in thinking that Catholics could not be(come) loyal citizens because they had sworn allegiance to the Pope, but he was right in pinpointing the source of the malaise that still haunts the European nation states: 'it is not the diversity of opinion, which cannot be avoided, but the refusal of toleration to those that are of different opinions, which might have been granted, that has produced all the bustles and wars, that have been in the Christian world upon account of religion.' ${ }^{79}$ Barry, Finnis \& Co may or may not be right in heralding a new 'Dark Age,' but they are certainly wrong in diagnosing the nature of the threat. Where national majorities unilaterally impose their traditions and cultures on religious minorities under the weak disguise of defending secular state neutrality, backed up with the threat of removal from the polity, they jeopardize the very being and becoming of political community. Under such conditions, liberals indeed cannot afford the 'luxury of unilateral disarmament. ${ }^{80}$ 